\title{
MODEL PELATIHAN KEWIRASWASTAAN BIDANG JASA KETERAMPILAN OTOMOTIF
}

(Studi Tentang Pemuda Putus Sekolah di Kecamatan Sukasari Bandung)

\author{
Inu Hardi Kusumah \\ Dosen Jurusan Pendidikan Teknik Mesin, FPTK UPI
}

\begin{abstract}
ABSTRAK : Penelitian ini mengambil topik tentang model pelatihan kewiraswastaan bidang jasa keterampilan otomotif . Penelitian dilakukan dengan metode penelitian dan pengembangan (research and development) dengan pendekatan pokok kualitatif. Instrumen yang digunakan adalah berupa angket, wawancara, observasi dan tes. Hasil penelitian menunjukkan bahwa: Penyebab Remaja putus sekolah yaitu (a) faktor psikologis keremajaannya, (b) faktor ekonomi orang tua dan (c) faktor lingkungan tempat mereka tinggal. Pengembangan model konseptual dirancang dengan pendekatan analisis kebutuhan latihan dengan beberapa kegiatan: (a) rekrutmen peserta, (b) penentuan patok duga kompetensi, (c) penjadwalan, (d) fasilitas dan tempat, (e) pelaksanaan dan evaluasi program.Model empirik dihasilkan merupakan pengembangan model konseptual melalui validasi, analisis dan kesekapatan bersama antara peneliti, PKBM, Perguruan Tinggi, pihak pengusaha dan beberapa ahli dalam bidang pelatihan.Hasil uji coba dan implementasi model empirik pelatihan kewiraswastaan bidang jasa keterampilan otomotif menunjukkan adanya ketercapaian tujuan, sehingga model empirik tersebut dikatakan efektif.
\end{abstract}

Kata Kunci : kewiraswastaan, keterampilan otomotif, pelatihan

ABSTRACT: The title of the research is "The Model of Entrepreneurship Training for Automotive Vocational Skills". The approach of this research is research and development, in which the main approach is qualitative that is complemented with the quantitative approach in order to obtain the preliminary exploration data. The instruments of research are questionnaire, interview, observation and test. The findings of research indicate as in the follow:The causes of the juvenile dropped out of school are the factors of the: (a) juvenile psychological, (b) economic of family, and (c) environment where they live. The development of conceptual model to solve the problems of juvenile dropped out of school can be designed by using the approach of needs assessment analysis for training. The activities are required in the development of conceptual model are: (a) recruitment of trainee candidates, (b) determination the hypothesis of competency, (c) scheduling, (d) facilities and area/(building for training), and (d) implementation and program evaluation.The empirical model was developed based on the conceptual model through the validation, analysis, and shared agreement among the researcher, community learning centre (PKBM), university, entrepreneurs and training specialists.The finding of try-out and implementation of empirical model of entrepreneurship training for automotive vocational skills indicated the availability aim and objective achievement; and that's why it can be stated that the empirical model is effective.

Key word: entrepreneurship, otomotive skill, training 


\section{PENDAHULUAN}

\section{Latar Belakang Masalah}

Sebanyak 8224 keluarga yang termasuk kateri miskin di Jawa Barat menyebabkan pemuda putus sekolah di kota Bandung cukup tinggi. Faktor ekonomi dari para orang tua ternyata salah satu penyebab tinggginya angka putus sekolah pada anak usia antara 10-16 tahun. Hal ini sunggguh ironis karena sebetulnya pemerintah sudah memberlakukan wajib belajar 9 tahun dengan tanpa dipungut uang bayaran dari para siswa, bahkan malah para siswa dibantu langsung dengan bentuk bea siswa dan sebagainya.

Kebijakan dan program yang dijadikan upaya pemerintah kota Bandung, tampaknya sebagian besar masih bersifat bantuan langsung. Hal ini tentunya, perlu mendapat perluasan gagasan atau ide-ide untuk membantu pemecahan permasalahan kemiskinan perkotaan. Hal tersebut menarik perhatian penulis untuk mencoba mencari alternatif model pendidikan dan pelatihan Kewiraswastaan bidang jasa keterampilan otomotif. Diperlukannya sikap kewiraswastaan bagi para pemuda agar nantinya mereka dapat mengembangkan usaha mandiri, sehingga dapat membuka lapangan pekerjaan bagi dia sendiri dan orang lain. Kemampuan berwiraswasta tersebut akan sangat baik jika mereka punya suatu keterampilan dasar tententu misalnya keterampilan otomotif tentang perbaikan dan perawatan sepeda motor. Hal ini dengan melihat perkembangan kendaraan bermotor sekarang khususnya sepeda motor yang jumlahnya puluhan dan ratusan ribu dan tentunya dalam beberapa waktu yang akan datang diperlukan jasa perawatan dan perbaikannya. Inilah yang menjadi peluang prospektif pada masa yang akan datang bagi para pemuda putus sekolah.

\section{KAJIAN PUSTAKA}

\section{Pengertian Kewiraswastaan}

Pengertian kewirswastaan dalam pengertian umum, sesungguhnya telah berkembang sejak tahun 1700 dan berkembang pada dekade 1883-1950 yang digulirkan oleh ahli ekonomi Joseph Schumpeter (1883-1950) dalam House, Raplh (1988). Pengertian diorientasikan pada suatu inovasi dan kreatitivitas pemberdayaan, dan fokus pada. The entrepreneur carries out new combinations, 
thereby helping render old industries obsolete. Established ways of doing business are destroyed by the creation of new and better ways to do them.

Istilah ini, selanjutnya dikembangkan dalam wacana Indonesia, sebagai upaya perbaikan ekonomi dan produktivitas masyarakat. Kata wiraswasta dan wirausaha banyak ditemukan dalam kepustakaan berbahasa Indonesia, sehingga seringkali kata wirausaha digunakan dan yang lainnya kata wiraswasta. Apabila kedua kata tersebut ditelusuri isi dan maknanya, dapat diketahui bahwa setiap kepustakaan memabahas masalah yang sama yaitu tentang; mental sikap, dan perilaku berusaha mandiri.

Ditinjau dari sudut pandang psikologis, wirausaha lebih luas dari wiraswasta, karena di dalam wirausaha terdapat mental wiraswasta, hanya wiraswasta khusus membicarakan tentang kemampuan seseorang melakukan aktivitas di bidang usaha (industri dan perdagangan).

Secara etmologis wiraswasta merupakan istilah dati kata wira dan swasta.Wira berarti berani, utama atau prakarsa, sedangkan swasta merupakan paduan dua kata swa dan asta. Swa artinya sendiri, dan asta berarti berdiri.Swasta dapat diartikan berdiri menurut kekuatan sendiri. Oleh sebab itu, wiraswasta dapat diartikan keberanian, keutamaan serta keperkasaan dalam memenuhi kebutuhan serta memecahkan masalah hidup dengan kekuatan yang ada pada diri sendiri.

Seringkali kata wiraswasta diakitkan dengan kegiatan atau peran seseorang di perusahaan swasta, padahal arti dan maksud dan istilah wiraswasta tidak hanya terbatas pada orang yang berfungsi dalam perusahaan swasta, tetapi dapat ditemukan dalam berbagai lapangan kehidupan dan organisasi, bahkan di lembaga swasta maupun pemerintahan.Wiraswasta adalah orang yang berorientasi prestasi dan meyakini bahwa mereka menguasai nasib mereka sendiri, tidak bergantung pada orang lain untuk dukungan emosional dan merupakan individu yang sangat diarahkan oleh dirinya sendiri. Bygrave W.D (1994), mengemukakan bahwa wiraswasta adalah orang yang memanfaatkan kesemapatan, memprakarsai sesuatu gagasan/ide baru dan berusaha mewujudkannya, tidak membiarkan segala sesuatunya berfungsi secara rutin atau berlangsung menurut apa adanya, namun selalu berusaha apa yang dilakukan esok hari harus lebih baik dari hari ini. 
Mendiskusikan kewiraswastaan berarti mengkaji tentang "perilaku” yang meliputi, pengambilan inisiatif, mengorganisasi dan mereorganisasi mekanisme sosial dan ekonomi terhadap sumber dan situasi ke dalam praktik dan penerimaan risiko atau kegagalan. Menurut sudut pandang teori ekonomi, jiwa wiraswasta dalam mengelola kegiatan usaha. Kegiatan usaha ini pada dasarnya merupakan upaya mengorganisasikan bakat, kemampuan, dan motivasi untuk mengolah sumber ekonomi, sumber alam, tenaga, modal dan keahlian, setelah melalui proses tertentu memiliki nilai tambah dan menjadi sesuatu yang baru bagi kebutuhan masyarakat.

Drucker (1995) mengemukakan seorang wiraswasta selalu mencari perubahan, menanggapi, dan memanfaatkan sebagai suatu peluang. Orang yang memiliki jiwa wiraswasta tinggi tak akan melakukan kegiatan atau mengambil keputusan tanpa dampak positif yang jelas akan hasilnya.

Wiraswasta merupakan perilaku dari pada gejala kepribadian, pada dasarnya terletak pada konsep dan teori kemasyarakatan. Terdapat tiga faktor yang meletakkan dasar yakni konsep "tripod”, yang saling terkait, meliputi ” orang, tugas dan konteks organisasi”.

Orang mempunyai konsep motif, gaya hidup dan keterampilan, tugas berkaitan dengan yang dilakukan seorang wiraswasta mencakup apa yang harus dikerjakan, peran apa yang dimainkan di dalam organisasi, bisnis apa yang dilakukan, teknologi apa yang digunakan, serta jenis informasi apa yang dibutuhkan. Adapun terkait dengan konteks organisasi, seseorang menciptakan konteks organisasi yang lebih baik dengan visi pribadi sesuai dengan tujuan dan lingkungan yang mendukung. Jadi konteks organisasi ini bersifat laten di dalam visi wiraswasta dan perlu direalisasikan.

Bertolak dari uraian yang dikemukakan menunjukkan bahwa diskusi kewiraswastaan mempunyai makna; 1) sifat keberanian, keutamaan dan keperkasaan dalam memenuhi kebutuhan serta memcahkan masalah hidup dengan kekuatan yang ada pada diri sendiri, meyakini bahwa merekalah yang menguasai nasib mereka, tidak bergantung pada orang lain untuk dukungan emosional; 2) kemampuan memadukan pengetahuan, keterampilan, sikap peluang, keuangan, serta mengelola sumber daya yang ada di lingkungan guna mencapai tujuan. 


\section{Definisi dan Ruang Lingkup Pendidikan dan Latihan}

Pengembangan (training and development) pelatihan dan pengembangan merupakan salah media yang penting bagai manajemen untuk mencapai sasaran perusahaan atau organisasi secara efisien. Pelatihan dapat dilaksanakan di dalam atau di luar organisasi, sesuai dengan kebutuhan dan kemampuan penyelenggaraannya. Manfaat pelatihan dapat dilihat dari kebutuhan jangka pendek atau jangka panjang, seperti tujuan untuk mengantisipasi perkembangan Iptek yang digunakan atau dikembangkan, atau untuk kepentingan yang bersifat mendesak karena adanya perubahan teknologi, manajemen, dan layanan.

Salah satu dampak dari pelatihan, pada dasarnya adalah bagian penting dari pengembangan keahlian bagi masyarakat termasuk remaja putus sekolah. Hal itu, dapat dipandang dari konteks penciptaan kondisi di mana seseorang dapat bekerja keras memanfaatkan segala potensinya sebaik-baiknya. Jadi, ada dua syarat pokok untuk pengembangan karier yaitu kerja keras dan adanya potensi untuk berkembang.

Pengembangan keahlian juga tidak berarti memilih suatu jabatan tertentu sebagai tujuan kariernya dan menentukan langkah-langkah untuk mencapai tujuan. Hal disebabkan, manusia mempunyai perkembangan yang tidak tetap, keinginan, minat dan kemampuan dapat berubah sehingga jabatan yang semula ditentukan tidak lagi cocok atau malah dihapuskan karena perkembangan organisasi. Dengan demikian, pengembangan karier harus bersifat dinamis, disesuaikan dengan keadaan dan merupakan bagian integral dari organisasi.

Konsep pendidikan dan latihan sebagai salah satu media pengembangan kualitas SDM dalam organisasi, telah dibahas beberapa ahli sesuai dengan sudut pandang yang dilandasi oleh perspektif masing-masing. Untuk memperoleh informasi berkenaan dengan konsep tersebut, dapat diungkapkan beberapa pendapat di bawah ini.

Randall S. Schuler (1996:392), mendefiniskan pendidikan dan latihan adalah:

Training and development is any attempt to improve current or future employee performance by increasing, through learning, an employee's ability to perform, usually by increasing the employee's skills and knowledge. The need for training and development is determined by the employee's performance deficiency, computed as follows: Standard os desired 
performance (present or future), (a) actual (present or potential) performance; (b) training and development need.

Definisi yang diungkapkan, memberikan deskripsi berkenaan pelatihan dan pengembangan pada dasarnya merupakan pemberdayaan personil baik untuk kepentingan langsung meningkatkan kinerja, maupun untuk masa depan organisasi. Latihan dan pengembangan pengatahuan dan keterampilan, yang diikuti oleh para peserta disajikan berdasarkan kepentingan sesuai dengan standar kinerja masa kini dan masa depan. Standar masa kini, mengacu pada potensipotensi kinerja aktual, sedangkan standar lain adalah sesuai dengan kebutuhan masa depan dari kinerja personil maupun organisasi.

James W. Walker (1992:212), mengemukakan bahwa training aneducation are central element in the process of developing employees. Titik beratnya pada pengembangan kemampuan dan keterampilan karyawan.

Pendapat-pendapat tersebut, nampaknya mempunyai makna yang sama yakni bertumpu pada pengembangan personil dalam konteks aktivitas organisasi untuk mencapai tujuan. Ruang lingkup pendidikan dan latihan, mengacu kepada hasil analisis kebutuhan organisasi sesuai dengan peluang-peluang penyelenggaraanya. Hal tersebut dilandasi oleh tiga hal utama, yaitu; a) hasil analisis pada organisasi bahwa pendidikan dan latihan sangat dibutuhkan; b) hasil analisis operasional, berkenaan dengan isi program, peserta, dan keuntungan-keuntungannya, c) hasil analsis individu dari personil yang ada berkenaan dengan keahlian, kinerja, dan kemungkinan pengembangan kariernya

Faktor yang menjadi perhatian dalam proses analisis organisasi, yakni kebutuhan dan alokasi yang sesuai pada saat ini, dan masa yang akan datang. Selanjutnya dipertimbangkan apakah perlu mengadakan pendidikan dan latihan, jika tidak mungkin dilaksanakan perlu dicarikan alternatif pemecahan masalahnya. Namun jika danggap penting dan mendesak, maka perlu segera dianalisis operasionalnya, Seperti perilaku yang spesifik berkenaan dengan tuntutan kemampuan dan keterampilan, dan bagaimana kondisi tersebut saat ini. Tahap berikutnya mempertimbangkan pelaksanaan, dan keputusannya dapat dilaksanakan baru mefokuskan pada analisis personil berkaitan dengan pengetahuan, keterampilan dan sikap. Pelaksanaannya, dipertimbangkan pada dua 
pilihan pertama kepentingan kinerja secara langsung dan tingkat optimalisasi kinerja. Pertimbangan-pertimbangan tersebut, setelah dicari alternatif pilihan keputusan maka dievaluasi kembali secara sirkulasi.

Training dalam pelaksanaannya, tidak hanya bersifat tatap muka tertutup dalam suatu ruangan akan tetapi banyak ragamnya sesuai dengan tujuan, anatara lain: 1) On the job practical instruction, 2) Job rotation, 3) Supervised project work, 4) Programed learning, 5) Coaching, 6) Languange laboratories, 7) Pres cribed reading.

Wayne F. Cascio (1955:238) mengemukakan pula bahwa untuk mencapai keberhasilan pelaksanaan pendidikan dan latihan, perlu ditentukan indikatorindikator dan hubungannya dengan kebutuhan personil dan organisasi. Selanjutnya diungkapkan bahwa, fase pertama dalam menentukan indikator yang dimaksudkan, adalah penilaian terhadap kebutuhan pengajaran, objek atau arah materi program. Fase kedua adalah pengembangan pelatihan, berkenaan dengan menyeleksi media latihan yang tepat, dan peraturan pelatihan. Fase ketiga adalah evaluasi, mulai dari pengembangan kriteria, tes peserta, monitoring pelatihan, evaluasi pelatihan dan evaluasi transformasi pengetahuan, keterampilan dan sikap.

\section{METODE}

\section{Disain Penelitian}

Produk akhir yang diharapkan dari hasil penelitian ini adalah rumusan rancangan alternatif pengembangan sumber daya pendidikan luar sekolah, khususnya meningkatkan sikap mental kewiraswastaan.Untuk mencapai tujuan tersebut, penelitian ini dilakukan dengan pendekatan Research and Development melalui studi eksplorasi dan ekspektasi serta pengembangan.

Langkah pertama, melakukan studi pendahuluan melalui kajian pustaka bertujuan untuk mendapatkan pemahaman konseptual berkenaan dengan kerangka berpikir, sebagai landasan dalam menemukenali fenomena sebagai gejala yang menggambarkan adanya masalah pada remaja putus sekolah dikaitan dengan kemungkinan adanya peluang untuk mempunyai bekal keterampilan dan sikap kewiraswastaan. Hal itu, akan memandu peneliti dalam menganalisis kesenjangan antara teoretis dengan praktik di lapangan yang terkait dengan 
permasalahan remaja putus sekolah di kota Bandung.

Langkah kedua, menetapkan unit analisis kasus, melalui teknik dan penyusunan kisi-kisi instrumen, teknik pengumpul data, teknik pengolahan data, dan menyiapkan angket dan format isian untuk digunakan sebagai alat eksplorasi latar belakang partisipan dan analisis kebutuhan.

Langkah ketiga, menyusun perencanaan program dan model pelatihan kewiraswastaan bidang keterampilan otomotif, menyangkut analisis kebutuhan pelatihan remaja putus sekolah, kurikulum pelatihan, silabus, penyusunan jadual, rencana pelatihan, bahan ajar dan media belajar, sistem penilaian serta penetapan tim pengajar.

Langkah keempat, melaksanakan model terbatas pada unit analisis kasus, menyangkut instrumen, pelatihan terbatas, bahan ajar dan alat, instruktur dan waktu harian selama kurun waktu seminggu.

Langkah kelima, melaksanakan validasi dan revisi model pelatihan kewirausahaan melalui, lokakarya mendatangkan ahli.

Langkah keenam, melaksanakan pelatihan sesuai dengan model, prosedur, rancangan uji kelayakan, dan strategi pelatihan melalui tahapan teori, praktek dan magang di beberapa bengkel otomotif. Selama proses dipantau untuk dilakukan, monitoring dan pemantauan sebagai bagian dari penilaian portofolio.

Mengingat dalam penelitian ini bersifat pengembangan dan studi kasus, maka tidak mempertimbangkan populasi sebagai analisis, melainkan bersifat terbatas pada kasus yang dianalisis. Oleh sebab itu, dalam penelitian ini yang menjadi kasus para remaja putus sekolah di kecamatan Sukasari kota Bandung.

Teknik sampling dalam penelitian ini, menggunakan purpose sampling sesuai dengan luas permasalahan serta keterbatasan yang terjadi, sehingga dalam menentukan sampel didasarkan data yang diperlukan. Populasi dalam penelitian ini adalah remaja putus sekolah yang tersebar di kecamatan Sukasari.

Dalam rangka mengidentifikasi sejumlah karakteristik yang berkaitan dengan permasalahan yang diteliti, ataupun sumber-sumber yang dipandang dapat memberikan informasi tentang jumlah, minat dan bakat para remaja putus sekolah yang erat kaitannya dengan proses pendidikan dan pelatihan di wilayah kasus tersebut dipilih informan sebagai berikut: Pada tingkat institusi, terdiri dari satu 
orang koordinator PKBM, satu orang Camat, lima kepala kantor kelurahan, satu orang pihak berwenang dari Perguruan Tinggi dan lima orang pengusaha yang ada di kota Bandung, dan informan lain yang dipandang relevan untuk memberikan informasi atau penilaian tentang sesuatu hal.

Pengumpulan data berdasarkan kondisi nyata para remaja putus sekolah, khususnya yang terkait dengan masalah keluarga, latar belakang sosial ekonomi, minat dan bakan yang dapat dikembangkan. Selain itu, institusi mana yang dapat berperan serta dalam program pendidikan dan pelatihan penanaman sikap kewirausahaan serta pembekalan keterampilan teknis otomotif pada tingkat kesiapan berusaha mandiri. Untuk memperoleh data yang diperlukan sesuai dengan aktivitas, digunakan beberapa teknik pengumpulan data, yaitu: Studi kepustakaan, Observasi, Kuesioner, Uji coba model.

\section{HASIL DAN PEMBAHASAN}

\section{Faktor dominan Penyebab putus sekolah dan keminatan untuk berwiraswasta}

Temuan dalam penelitian ini yang paling mendasar, adalah menanamkan kondisi negentropy yakni; berbagai informasi melalui interaksi pelatihan, diharapkan dapat disadari sebagai modal kepercayaan diri, dan membekali kemampuan menghubungkan pengetahuan yang satu dengan pengetahuan yang lain dan memahami manfaatnya bagi kehidupan.

Peneliti berpandangan bahwa, kompleksitas pendidikan luar sekolah tidak hanya persoalan institusi semata-mata, atau keunggulan program melainkan aspek kompetensi dan profesionalisme pelayanan yang terlibat dalam merespons kondisi masyarakat sangat strategis.

Orientasi pendidikan luar sekolah, pada masa depan harus dibangun oleh kekutan Tim Work yang ditopang oleh kepakaran dan praktisi. Keterlibatan sosiolog, antropolog, psikolog dan pemuka agama, merupakan dasar dalam menganalisis pemecahan masalah, termasuk remaja putus sekolah diperkotaan.

Peneliti mengeksplorasi keminatan Berwiraswasta pada remaja putus sekolah, menunjukkan bahwa pada dasarnya para remaja putus sekolah dalam kondisi serta pada situasi komunitas yang dipandang kurang kondusif, ternyata masih 
mempunyai potensi untuk berkembang dengan dicirikannya oleh; (1) kemauan; (2) ketekunan; (3) tangungjawab; (4) kemandirian dan (5) kreativitas. Komponen tersebut, pada saat ini mereka dengan cara dan jalan yang ditempuh tanpa pembimbingan sistemik dan terarah.

Setiap pribadi, dari data yang ada telah melakukan berbagai aktivitas sesuai dengan potensinya, mulai dari bekerja serabutan membantu orang lain, menjadi tukang ojek, dan tukang parkir tidak resmi. Hal itu, dilandasi oleh keinginan membantu ekonomi orang tua mereka, minimal untuk memenuhi kebutuhannya. Namun demikian, perkembangan tersebut tidak selalu sesuai dengan norma-norma atau pranata lingkungan pada kondisi normal. Sehingga sering kali ada efek negatif terutama pemanfaatan hasil usaha mandirinya kurang bermakna, seperti digunakan untuk membeli miniman keras, atau perilaku lain yang dipandang menyimpang dari norma.

Kondisi yang dihadapi para remaja putus sekolah tersebut, tentunya tidak terlepas dari perkembangan dirinya dalam komunitasnya. Sehingga potensi positif yang ada, terbawa oleh kekuatan potensi negatif yang terjadi pada lingkungan. Persoalan tersebut, tentunya harus dicari akar masalahnya yakni melalui penyadaran komunitas remaja putus sekolah di mana ia berada.

Walaupun demikian, peneliti masih mempunyai harapan adanya perbaikan dari kondisi ketidakstabilan emosi remaja putus sekolah ke arah positif. Salah satunya, dibuktikan oleh data bahwa mereka mempunyai kekuatan untuk berkeinginan memperbaiki kehidupan ekonomi, melepaskan diri dari kesulitan orang tua pada aspek materi. Melalui cara mereka mencari jalan untuk memenuhi kebutuhannya, ditunjukkan oleh ketekunan hidup dijalanan, tanggung jawab terhadap apa yang dilakukannya, dan kreativitas dalam bersaing dengan komunitasnya.

Model Konseptual Pemecahan Masalah Remaja Putus Sekolah dalam Konteks Pendidikan Luar Sekolah

\section{a. Deskripsi Konseptual Kemitraan antara PKBM, Pemerintah Setempat, Pengusaha dengan Perguruan Tinggi}

Kerangka kerja pemecahan masalah, seperti ditunjukkan pada skema gambar 1 kemitraan PKBM dapat dikemukakan langkah sebagai berikut: 


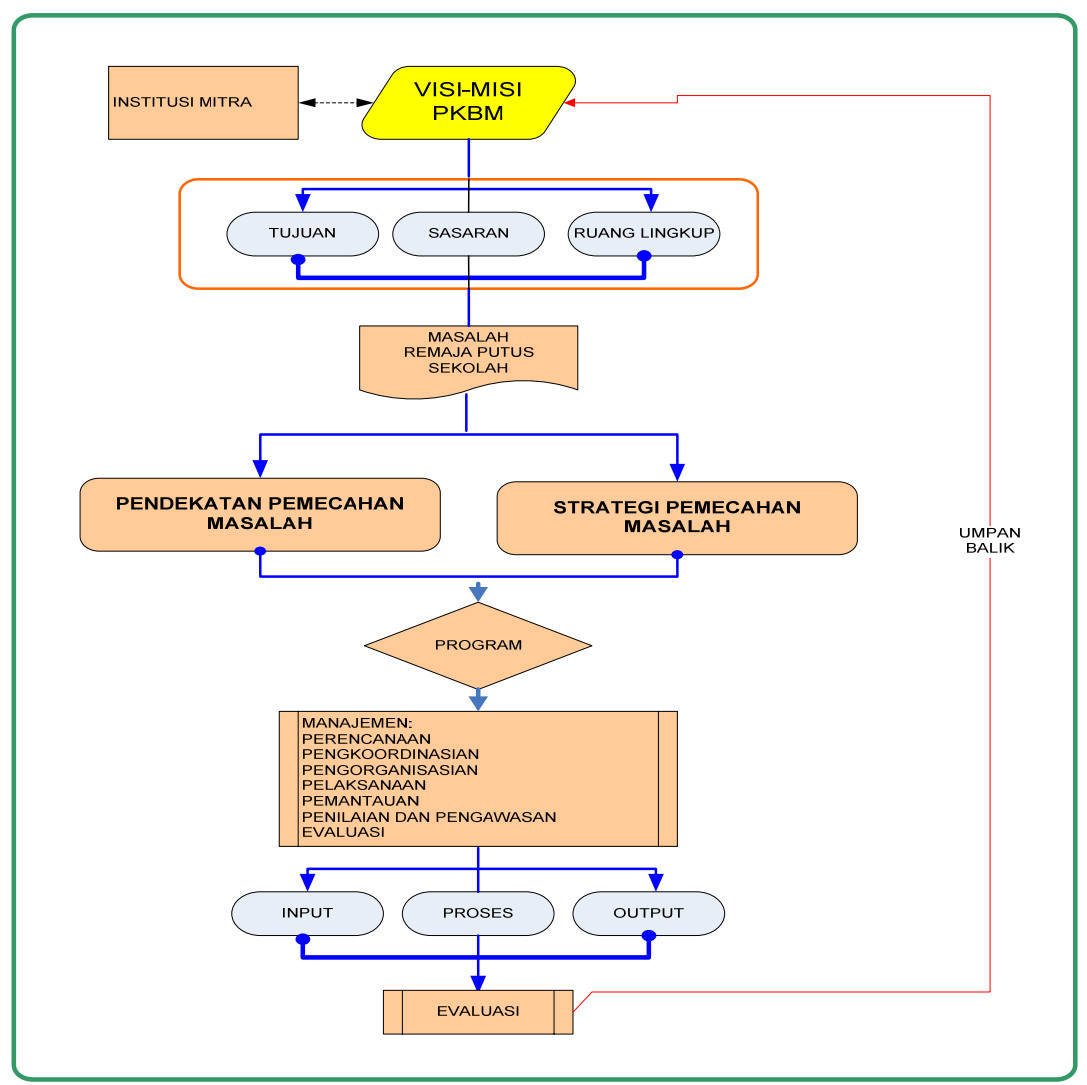

Gambar 1: Model konseptualkemitraan PKBM untuk pemecahan masalah remaja putus sekolah

Sebagai upaya pemecahan masalah, dalam konteks manajemen PKBM berdasarkan temuan penelitian ditemukakan sebagai berikut:

(1) PKBM sebagai institusi Pendidikan Non Formal yang berfungsi sebagai koordinator pembangunan pendidikan di lingkungan wilayah yang relatif kecil pada konteks masyarakat yang tersebar di kabupaten dan kota dalam konteks pendidikan luar sekolah (Non Formal).

(2)PKBM dalam membangun kemitraan merupakan salah satu modal dasar yang harus terus dikembangkan. Hal itu, terkait dengan pemberdayaan potensi sumber-sumber daya dalam sistem manajemen pada organisasi kemasyarakatan khususnya dalam masalah pendidikan luar sekolah.

(3) PKBM mempunyai pengalaman dalam pengembangan potensi masyarakat dan telah dikenal secara kelembagaan dan pelayanan pendidikan luar sekolah.

Pendekatan pemecahan masalah dapat diuraikan sebagai berikut: 
(a) Pengembangan Kemitraan

Peneliti, mendefinisikan tujuan pengembangan kemitraan, hakikatnya adalah upaya kolektif (ketokohan individu, institusi pemerintahan, institusi perguruan tinggi dan lembaga swadaya masyarakat, dan kelompok profesional yang ada di lingkungan masyarakat lokal dan nasional) meliputi:

- Penyegaran kembali hubungan kemitraan untuk tujuan pemecahan dan penanggulangannya masalah remaja putus sekolah

- Pemutakhiran program kerjasama untuk tujuan pemecahan dan penanggulangannya masalah remaja putus sekolah

- Perbaikan berkelanjutan pemecahan dan penanggulangannya masalah remaja putus sekolah

- Memberikan dampak pada mutu pendidikan luar sekolah

- Sebagai proses pembentukan akuntabilitas yang menjadi modal sosial kepada masyarakat

(b) Akurasi dan Optimalisasi Pendataan

PKBM harus mampu melaksanakan sistem pendataan dan pemutakhiran data berkenaan dengan masyarakat perkotaan, terkait dengan kondisi geografi kewilyahan, kondisi sosial ekonomi, budaya masyarakat kota, psikologis masyarakat kota, secara mikro (kecamatan, kelurahan sampai dengan RT).

(c) Rasio dan Kualitas SDM

PKBM harus idbantu oleh para pekerja sosial, melalui rekrutment dan pendekatan lintas budaya,ekonomi sosial dan agama agar diperoleh sekelompok polentir dan petugas profesi berdasarkan rasio kebutuhan dengan landasan perhitungan data. Artinya, PKBM harus mendefinsikan layanan primer, sekunder dan tersier secara akurat.

Proses yang dilaksanakan oleh peneliti, dalam melakukan kerjasama program pelatihan kewirausahaan bidang keterampilan otomotif khususnya sepeda motor dengan pihak-pihak terkait, mencakup:

(1) Pengusulan program kerjasama pelatihan atas dasar penelitian dan pengembangan

(2) Penjaminan keterlaksanaan manajemen pelatihan

(3) Permintaan adanya dukungan berbagai kemungkinan dari pihak terkait 
Hasil yang disepakati dari institusi mencakup:

(a) Pihak PKBM Tirtasari,

Prinsipnya menyepakati adanya kegiatan penelitian dan pengembangan bagi remaja putus sekolah di wilayahnya. PKBM terlibat dalam pemantauan dan pendampingan pelatihan, secara berkala membantu fasilitas pertemuan antara peserta dengan peneliti dan kelurahan.

(b) Pihak kelurahan Isola

- Memberikan rekomendasi serta memfasilitasi untuk memberikan rekomendasi kepada para remaja yang ikut dalam program pelatihan, melalui RW dan RT Setempat.

- Turut serta mendampingi pelaksanaan pelatihan di JPTM FPTK UPI

(c) Pihak kecamatan Sukasari

- Memberikan rekomendasi kepada para pengusaha bengkel sepeda motor untuk menerima praktikan pelatihan kewirausahaan.

- Memberikan dukungan dalam konteks kegiatan sosial dan kepemudaan di wilayahnya, melalui bantuan promosi peningkatan kualitas sosial lingkungan masyarakat

(d) Pihak Perguruan Tinggi,

Jurusan Pendidikan Teknik Mesin Fakultas Pendidikan Teknologi dan Kejuruan (JPTM FPTK) Universitas Pendidikan Indonesia, memberikan bantuan berupa fasilitas pelatihan dan pengembangan bahan ajar serta bantuan para instruktur yang memberikan pelatihan keterampilan otomotif.

(e) Pihak pengusaha bengkel sepeda motor

Memberikan fasilitas untuk magang dengan kapasitas 3 orang peserta setiap bengkel, dengan ketentuan normatif, yakni setiap peserta harus patuh terhadap peraturan yang diberikan oleh perusahaan, baik dalam melaksanakan tugas maupun perilaku dalam menjaga kepercayaan pada pelanggan. Selain itu, ada jaminan dari pihak peneliti bagi keberlangsungan saling kepercayaan adanya penitipan peserta magang, terutama kaitannya dengan keamanan dan keselamatan kerja. 


\section{b. Deskripsi Model Keterlibatan Institusi Perguruan Tinggi dalam Menanggulangi Remaja Putus Sekolah}

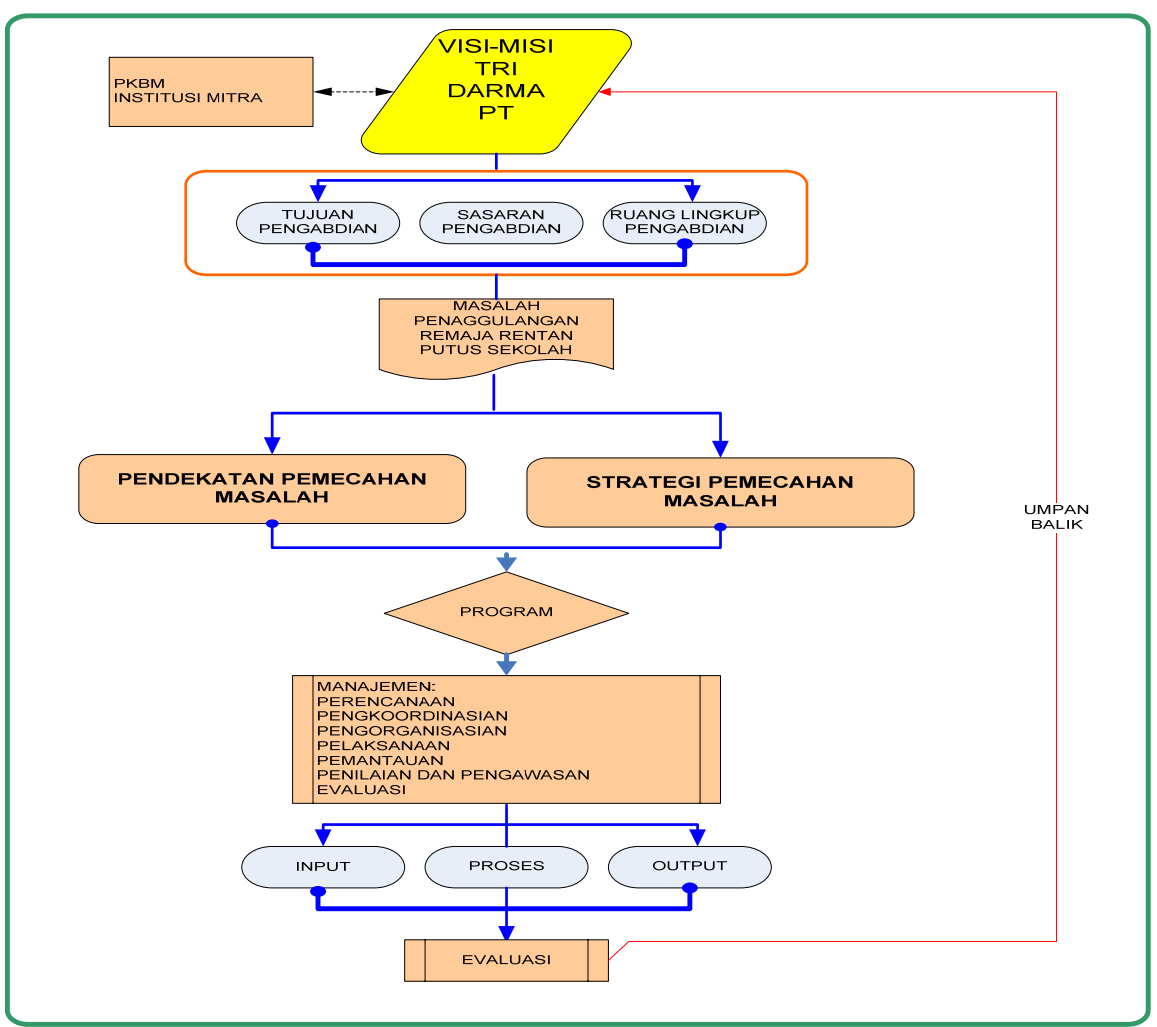

Gambar 2. Model konseptual keterlibatan perguruan tinggi dalam pemecahan masalah remaja rentan putus sekolah

Kerangka kerja pemecahan masalahditunjukkan pada skema Gambar 2, Pendekatan pemecahan masalah dapat diuraikan sebagai berikut :

(1) Pemetaan masalah secara makro (rod map)

Peneliti, mendefinisikan tujuan pemetaan makro (rood map), hakikatnya adalah melakukan pemetaan masalah pendidikan luar sekolah berdasarkan analisis peta masalah, analisis peta wilayah, dan karakteristik pada masingmasing kondisi sosial, ekonomi, budaya pada kelompok masyarakat. Upaya yang dilaksanakan selanjutnya dikaji secara komprehensif pada masingmasing fakultas dan program studi, sehingga diperoleh multi pendekatan pemecahan masalah berdasarkan kapasitas dari kelompok dan individu dosen, mencakup;

- Pengabdian masyarakat dirancang berdasarkan, permasalahan dan pemecahan masalah melalui pendekatan multi metod serta dilaksanakan 
bisa secara kolektif yang diwakili oleh setiap program studi yang relevan dengan permasalahan.

- Perbaikan berkelanjutan pemecahan dan penanggulangannya masalah dan dijadikan bagian terintegrasi dengan penelitian, yang bersifat kolaborasi pada tingkat fakultas atau universitas.

(2) Akurasi dan Optimalisasi Pendataan

Perguruan Tinggi melaksanakan sistem pendataan dan pemutakhiran data berkenaan dengan masyarakat perkotaan, terkait dengan kondisi geografi kewilyahan, kondisi sosial ekonomi, budaya masyarakat kota, psikologis masyarakat kota, secara mikro (kecamatan, kelurahan sampai dengan RT$\mathrm{RT})$.

\section{$\underline{\text { Kualitas Program }}$}

PT dalam melaksanakan manajemen pengabdian kepada masyarakat, harus berdasarkan pengajuan yang sistematis pada masing-masing tingkat program studi yang diajukan kepada lembaga pengabdian pada masyarakat.Selanjutnya direkomendasikan untuk dilaksanakan, baik yang berupa program biaya mandiri atau biaya dari universitas, Dikti dan sponsor lainnya.

\section{Ruang Lingkup}

Program yang akan dijadikan pemodelan adalah seperangkat sistem yang harus dilaksanakan oleh program studi, mencakup :

(a) Perencanaan, pengkoordinasian, pengorganisasian, pelaksanaan, pemantauan, penilaian dan evaluasi program pengabdian kepada masyarakat

(b) Koordinasi pelaksanaan di setiap program studi, fakultas dan dikoordinasikan oleh pihak lembaga di masing-masing PT

\section{Strategi dan Daya Dukung Implementasi}

Pengembangan kualitas pengabdian kepada masyarakat, dapat dilaksanakan melalui pendekatan yang sistimatis. Sebagai model konseptual startegi yang dikembangkan, melalui adaptasi dari Osborne dan Peter Plastrik ( 1997; 23-55) disebut sebagai 'Lima Strategi'. Adapun praktinya sebagai berikut:

(a)Strategi Inti

Untuk mencapai tujuan kualitas pengabdian kepada masyarakat sebagai bentuk Tri Dharma PT, maka setiap insan dosen di masing-masing program 
studi dapat menyadari pentingnya tugas tersebut.Titik berat dari strategi ini, adalah bagaimana membangun kesadaran dan budaya organisasi program studi, bahwa pengabdian kepada masyarakat sama pentingnya seperti tugas PBM dan penelitian.

(b) Strategi Konsekuensi

Selaras dengan tuntutan akreditasi dan penilaian kinerja PT, hasil perolehan dari pengembangan program pengabdian masyarakat menjadi salah satu gambaran penilaian mutu.Hal ini, dapat dijadikan konvensasi bagi masingmasing program studi, sehingga manfaatnya dapat dirasakan modal akuntabilitas.

(c) Strategi Pelanggan

PT dituntut mampu mempertanggungjawabkan tugas profesinya, baik diminta maupun tidak oleh pihak berwenang.Teristimewa bagi masyarakat, hal ini harus menjadi semangat organisasi dalam konteks akuntabilitasnya.

(d) Strategi Kontrol

PT dalam membangun kualitas pengabdian kepada masyarakat, harus mau dilakukan suatu pendekatan penilaian pihak eksternal, mulai dari supervisi sampai dengan akreditasi. Kondisi ini dapat dilaksanakan bekerjasama dengan pengawas pendidikan luar sekolah, dan atau pihak lain yang mempunyai kompetensi dan berkewenangan.

(e) Strategi Budaya

PT harus mampu menempatkan posisinya sebagai bagian dari budaya masyarakat di Jawa Barat khususnya di kota Bandung, yang mempunyai karakteristik kedaerahan yang positif. Artinya,citra kekeluargaan dalam ikatan kemasyarakatan sebagai konsentalasi sosial merupakan modal dasar. Oleh karena itu, budaya kekeluargaan dapat dijadikan semangat pencapaian tujuan kemitraan. 


\section{c. Tahapan Uji Coba dan Evaluasi Program Untuk mendapatkan model Empirik}

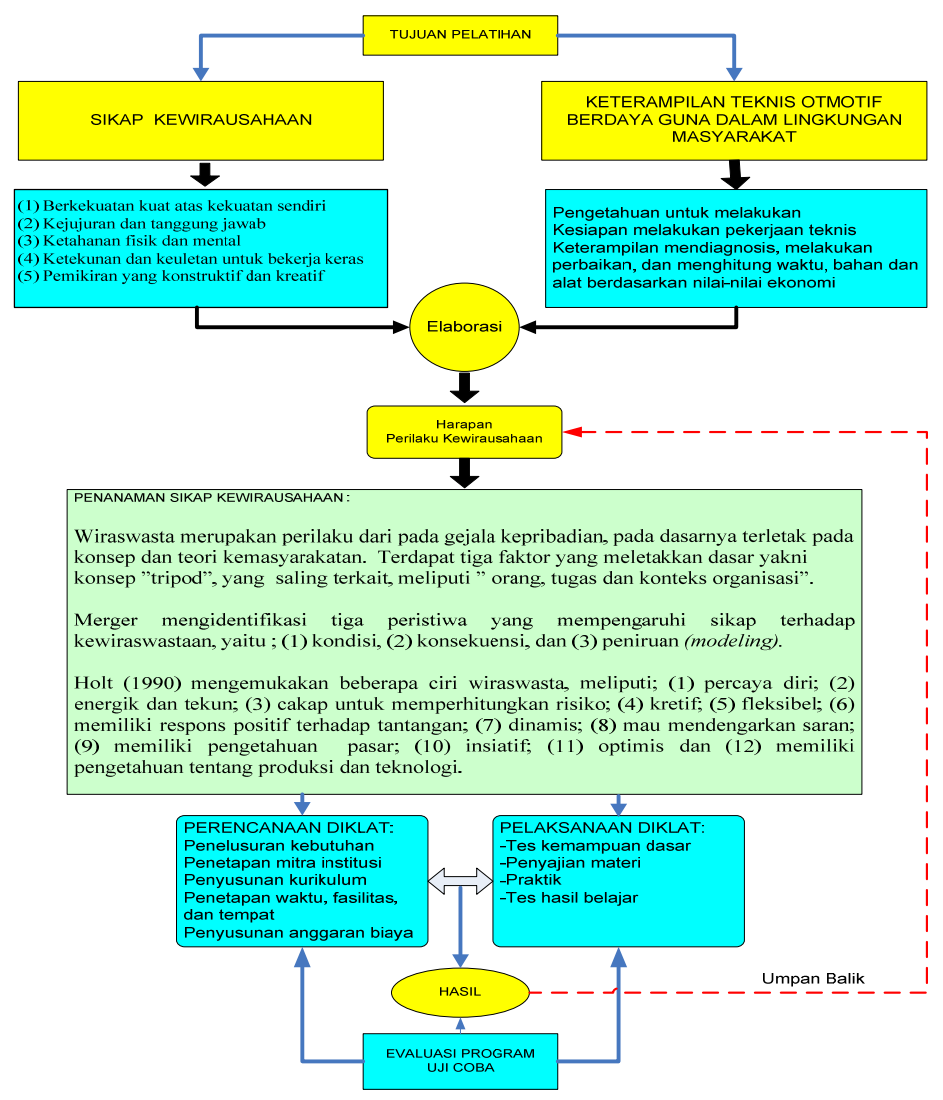

Gambar 3. Kerangka berpikir untuk membangun model

Tahap awal pelatihan terlebih dahulu dilakukan test pengetahuan tentang sepeda motor, terkait dengan teknologi, penggunaan dan manfaat serta pengetahuan pemeliharaannya. Secara umum, mereka mengetahui sepeda motor dari manfaatnya dan ada juga yang telah mengenal teknologinya, akan tetapi mengenai memelihara dan memperbaiki hampir sebagian besar peserta belum memahami dan melakukannya.

Temuan awal dari pelaksanaan pelatihan ini, adalah kesiapan menerima materi secara konseptual sangat lemah. Hal itu, disebabkan para peserta telah lama meninggalkan belajar secara klasikal, sehingga selama menerima pelajaran kurang perhatian. Selanjutnya diadakan perubahan dalam memberikan materi, yakni dengan langsung dihadapkan pada objek benda kerja, dan hasilnya sangat meyakinkan, bahwa mereka mampu dengan cara langsung. 
Instruktur dalam menghadapi peserta, memperoleh pengalaman baru dalam memberikan pelatihan kepada peserta yang latar belakang pendidikannya bervariasi. Pembelajaran untuk mencapai minimal dari kompetensi otomotif, dilaksanakan dengan pendekatan: (1) latihan tindakan; (2) tugas terstruktur; (3) diskusi; (4) praktik lapangan, dan (5) evaluasi kinerja. Pelaksanaannya didasarkan pada siklus keterampilan, mencakup; Lihat-Lakukan-Cocokan-Diskusikan-Baca Dimensi (LLCDBD).

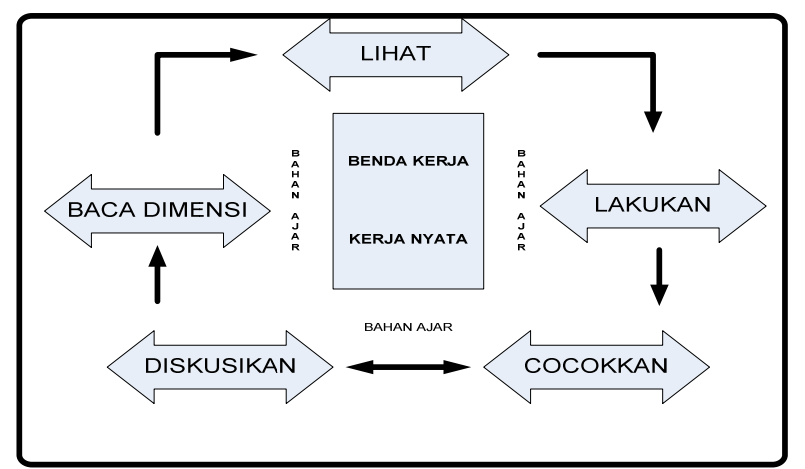

Gambar 4. Pendekatanpelatihan keterampilan

Tahapan pelatihan yang diikuti peserta selama kurang lebih 560 jam, setara dengan pelatihan untuk mencapai tingkat terampil (dasar plus), peserta dapat mendemonstrasikan kompetensinya pada dua model sepeda motor yakni motor dua langkah dan empat langkah pada jenis sport, bebek dan schooter.

Pengembangan kompetensi untuk sepeda motor, dilatihkan bagaimana bekerja sesuai dengan prosedur yang sudah ditetapkan pabrik, mereka harus mengusai diri dalam menjaga keselamatan kerja melalui dari pakaian, alat pelindung, penggunaan alat-alat bantu dan pengukur, serta langkah-langkah melakukan pemeliharaan, perawatan dan perbaikan komponen.

Temuan penelitian, menunjukkan bahwa sebagian besar peserta mempunyai kapasitas untuk mengembangkan keterampilannya. Oleh karena itu, para instruktur terus memberikan motivasi untuk membiasakan diri melakukan pekerjaan dengan disiplin, teliti, cermat dan kecepatan waktu penyelesaian.

Pelatihan yang menitikberatkan pada keterampilan teknis, peserta selalu diorientasikan pada kondisi simulasi tekanan, seperti menghadapi konsumen pada lingkungan pekerjaan di bengkel. Kondisi ini, sesungguhnya latihan untuk membangun karakter kesabaran. 
Selama 450 jam latihan (kurang lebih 3 bulan), paserta dilakukan penilaian berkala mulai dari penilaian proses kinerja dengan portofolio, test perbuatan, test tulis dan lisan. Hasilnya hanya satu orang dari 25 peserta yang dipandang belum layak untuk ditingkatkan kompetensinya.

Setelah dinyatakan layak mempunyai keterampilan dasar pemeliharaan dan perawatan sepeda motor, peserta dilatih mengenai sikap mental kewirausaan selama 110 jam ( satu bulan) dan 240 jam untuk magang. Pelatihan ini menitik beratkan pada penanaman nilai-nilai kewirausahaan, melalui metode diskusi, cermah instruktur tamu, dan simulasi.

Proses ini, memerlukan strategi dan pendekatan yang sesuai dengan kapasitas peserta, hasilnya sebagian besar ada kecenderungan untuk bangkit semangat dan kepercayaan dirinya.

Melatih pengembangan sikap, sesungguhnya lebih sulit diestimasi secara langsung berbeda dengan melatih keterampilan bersifat perilaku seperti keterampilan sepeda motor. Hal itu sejalan dengan, pendapat Hovland (1960 dalam Ajzen, 1988), menempatkan ketiga komponen afeksi, kognisi, dan konasi sebagai faktor jenjang pertama dalam suatu model hirarkis.

Dengan demikian para instruktur memerankan dirinya dalam konteks psikologis peserta. Interaksi belajar kewiraswastaan di lingkungan pelatihan, bukan hanya hubungan antara pengajar dan remaja, tetapi terjadinya interaksi antara remaja dengan materi kewiraswastaan dan pelajaran itu bermakna bagi remaja khususnya putus sekolah. Suatu pelajaran kewriswastaan akan bermakna jika dalam proses belajarnya dapat melibatkan emosi remaja. Adanya interaksi mendalam antara remaja dengan pelajaran kewiraswastaan diharapkan akan membentuk sikap positif remaja terhadap kewiraswastaan.

Sebagai upaya mengembangkan sikap kewiraswastaan selanjutnya, diujicobakan dengan pola magang di beberapa bengkel sepeda motor. Magang merupakan perwujudan dari pengkondisian, konsekuensi yang diahadapi dan sekaligus peniruan baik dalam aspek keterampilan teknis maupun keterampilan manajemen sederhana.

Peneliti memandang bahwa proses pelatihan sikap kewiraswastaan, hanya bisa efektif apabila peserta dibawa ke wilayah penerimaan, merasa adanya kebutuhan 
yang sesuai, dan ada harapan untuk meraih manfaatnya. Hal itu sejalan dengan pandangan Merger mengidentifikasi tiga peristiwa yang mempengaruhi sikap terhadap kewiraswastaan, yaitu; (1) kondisi, (2) konsekuensi, dan (3) peniruan (modeling) pengajar harus mampu menciptakan kondisi belajar yang menyenangkan bagi remaja.

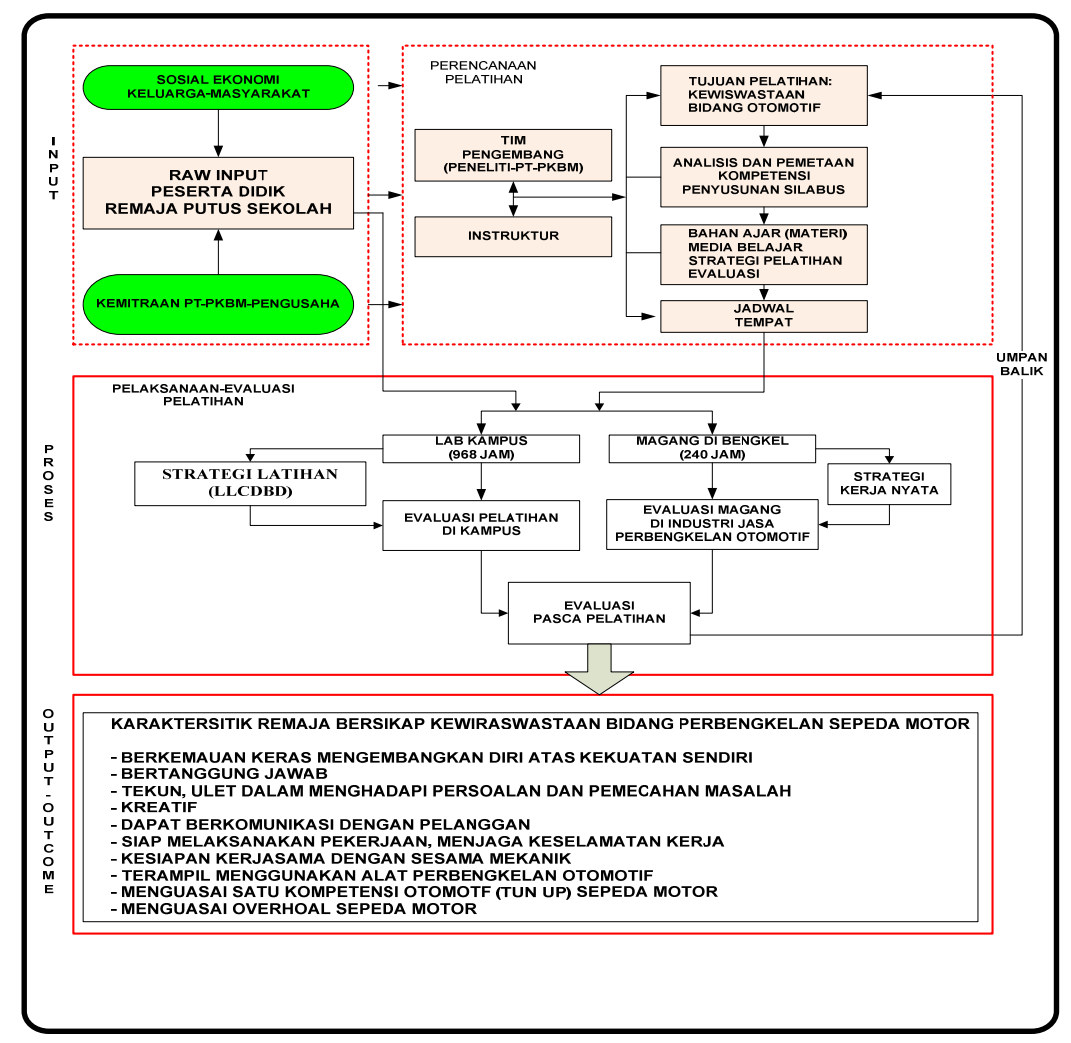

Gambar 5. Model konseptual pelatihan kewira-swastaan bidang jasa keterampilan otomotif yang telah dikembangkan

\section{KESIMPULAN}

Tiga faktor utama penyebab putus sekolah;adalah (1) faktor psikologis keremajaannya; (2) faktor ekonomi orang tua; dan (3) lingkungan sosial di mana mereka berada sebagai komunitas masyarakat. Ketiga komponen tersebut, satu sama lain saling tergantung, dan mempengaruhinya. Untuk faktor keminatan berwiraswasta pada dasarnya para remaja putus sekolah dalam kondisi serta pada situasi komunitas yang dipandang kurang kondusif, ternyata masih mempunyai potensi untuk berkembang dalam keminatan untuk berwiraswasta dengan dicirikannya oleh: (1) kemauan; (2) ketekunan; (3) tangungjawab; (4) kemandirian 
dan (5) kreativitas. Komponen tersebut, pada saat ini mereka dengan cara dan jalan yang ditempuh tanpa pembimbingan sistemik dan terarah.

Model konseptual pemecahan masalah remaja putus sekolah dirancang berdasarkan pendekatan analisis kebutuhan bersifat dinamik dalam konteks pencapaian tujuan pelatihan, yakni membekali sikap kewiraswastaan bidang jasa keterampilan otomotif (sepeda motor). Mulai dari rancangan rekrutment peserta, penetapan patok duga kompetensi, penjadualan, fasilitas dan tempat serta pembiayaan sampai dengan pelaksanaan dan evaluasi program.

Tahapan ini dilaksanakan berdasarkan pendekatan kemitraan dan kolaborasi dengan pihak-pihak terkait dengan masalah penanganan remaja putus sekolah .Model konseptual ini, dilanjutkan pada fase validasi kelayakan, fase ini melibatkan individu-individu di luar pembimbing, guna memperoleh penguatan terhadap kelaikan dan kelayakan penelitian dan pengembangan. Hasilnya diperoleh kesepahaman, bahwa model konseptual layak untuk dikembangkan.

Hasil uji coba dari ketiga komponen utama program pelatihan sikap kewiraswastaan mencakup; (1) keterampilan otomotif (sepeda motor); sikap kewiraswastaan; dan (3) magang di beberapa bengkel sepeda motor, menunjukkan adanya ketercapaian tujuan pada batasan yang telah ditetapkan. Batasan tersebut merujuk pada satuan baku kompetensi keterampilan pemeliharaan dan perbaikan sepeda motor.

Efektivitas program pelatihan melalui penelitian dan pengembangan, secara akademik dapat dikatakan optimal pada konteks output proses. Sedangkan outcome belum dapat diestimasi mengingat masih perlu adanya program yang berkesinambungan. Hal tersebut, mencakup pendampingan bagi peserta pasca pelatihan untuk memelihara keterampilan dan sikap kewiraswastaan yang telah dikembangkan. Kondisi tersebut memerlukan kekuatan yang sinerjik dari pihakpihak yang berwenang, guna mencapai kesejahteraan masyarakat melalui pembinaan remaja putus sekolah.

\section{DAFTAR PUSTAKA}

Abu Ahmadi dan Munawar Shoteh. (1991). Psiko- Perkembangan. Jakarta: Rineka Cipta. 
Anderson, John R. (1990). Cognitive Psychology and Its Implication.3rd. Edition.New York: W.H. Freeman and Company.

Anita E. Woolfolk dan Lorraine M. Nicolich, (1984). Educalional Psychology for Teachers (New Jersey: Prentice-Hall.

Ajzen, I. (1988). Attitudes, Personality, and Behavior, Milton Keynes: Open University Press.

Alien, D.E., Guy, R.F. \& Edgley, C.K. (1980). Social Psychology as Social Process. Belmont, Cal.: Wadsworth Publishing Company.

Barlow, Daniel Lenox. (1985). EducationalPsychology: The Teaching Learning Process. Chicago: The Moody Bible Institute.

Baron, R.A. \& Byrne, D. (1991). Social Psychology, Understanding Human Interaction, 6th edition. Boston, MA.: Allyn and Bacon, 1991.

Berkowitz, L. (1972). Social Psychology, Glenview, 111.: Scott, Foresman and Company.

Best, John B. (1985). Cognitive Psychology.2nd Edition. New York: Wet Publishing Company.

Biggers,J. (1980)."Body Rhythms, The School Day and Academic Acnievement", journal of Experimental Education, 49, 45-47.

Biggs, John B. (1985). The Role of Metalearning Study Process. British Journal of Educational Psychology, 55, 185-212.

Blank.E.W. (1982). Handbook For developing Competency-Based Training Programs.London: Prentice-Hall International,Inc

Brehm, S.S. \& Kassin, S.M. (1990). Social Psychology. Boston: Houghton Mifflin Company.

Brigham, J.C. (1991). Social Psychology, 2nd edition. New York: HarperCollins Publishers Inc.

Bruno, Frank J. (1987). Dictionary of Key Word in Psychology. London: Routledge \& Kegan Paul.

Burghardt, Gordon M. (1973).Instinct and Innate Behavior, dalam Navin, John E. (editor), The Study of Behavior. Illionis: Scott, Foresman and Co.

Cascio,W.F.(1995). Applied Psichology In Personal Management. New Jersey Prentice-Hall Inc.

(1995). Managing Human Resources: Productivity, Quality of Work Life, Profits. United Stated of America :McGraw Hill.

Dart, Barry C \& Clarke, John A.(1990). "Modifying The Learning Environmental of Students to Enhance Personal Learning”, dalam Bezzina, M \& Butcher, J. (editors), The Changing Face of professional education.Sydney: Australian Association for Research in education.

Davis, James. (2001). Effective Training Strategies. San Francisco: BereettKoehler Publishers,Inc 
Desller Gary. (1998). Human Resource Management. New Jersy : Prentic Hal inc.

DeHaan, R.F. and Havighurtst,R.J. (1957). Educating Gifted Children. Chicago: The University Press.

Dunn, Rita et al. (1989). Survey of Research on Learning Styles. Educational Leadership, 46, 50-58.

Edwards, A.L. (1957). Techniques of Attitude Scale Construction. New York: Appleton Century Croft, INC.

Elizabeth B. Hurlock. (1980). Developmental Psychology: A Life Span Approach. New Delhi: Tata McGraw Hill.

Evans, Glen. (1991). Introduction, dalam Evans, Glen (editor), Learning and Teaching Cognitive Skills. Howthorn: The Australian Council for Educational Research Ltd.

Feldman, R.S. (1985). Social Psychology - theories, Research, and Applications. New York: McGraw-Hill Book Company.

Fishbein, M. \& Ajzen, L. (1975). Beliefs, Attitude, Intention and Behavior: An Introduction to Theory and Research. Philippines: Addison-Wesley Publishing Company, INC.

Gable, R.K. (1986). Instrument Development in The Affective Domain. Boston, MA: Kluwer-Nijhoff Publishing.

Gordon H. Brower dan Ernest R. Hilgard. (1988), Theory of Learning.New York: Prentice-Hall.

Good, Thomas L. \& Brophy, Jere E. (1990). Educational Psychology: A Realistic Approach. 4th Edition. New York: Longman.

H.W.Dickson and Elliot. (1966). Affectivity and Arousal of Attitudees as Measured By Galvanic Skin Respons.Amirican Journal of Psicologi.

Hergenhahn, B.R. (1982). An Introduction to Theories of Learning 2nd edition.Englewood Cliffs, N.J.: Prentice-Hall, Inc.

Laatzko, W.J. (1986). Quality and Productivity for Bankers and Financial Managers. New York: Marcel Dekker, Inc.

Leslie Rae, (2005), Perencanaan Efektif (terjemahan) Effective Planning, The Art of Training and Development, Jakarta: PT Bhuana Ilmu Populer.

Luthans, F. (1995). Organizational Behavior. Singapore: McGraw-Hill International.

Kelly.L (1995). The ASTD Techincal and Skills Training Handbook.USA: McGraw-Hill,Inc

Mar'at, (1994). Sikap Mannsia: Perubahan serta Pengukurannya. Bandung: Ghalia Indonesia.

Middlebrook, P.N. (1974). Social Psychology and Modern Life. New York: Alfred A. Knopf, INC. 
Renzulli, J.S., Smith, L.H. (1981). The Revolving Door Identification Model Connecticut: Creative Learning Press,Inc.

Sax, G. (1980). Principles of Educational and Psychological Measurement and Evaluation, 2nd edition. Belmont: Wadsworth Publishing Company.

Steers, R.M and Porter, L.W. (1991). Motivation and Work Behavior. Singapore: McGraw-Hill International.

Surya, M.(1982). Psikologi Pendidikan. Bandung: FIP-IKIP.

Suryabrata, Sumadi. (1984). Psikologi Pendidikan. Jakarta: Rajawali.

Svenson.A Raynold, Rinderer J.M. (1992). The Training and Development Strategic Plan Workbook. USA: Prentice Hall

Walker. J.W. (1992). Human Resource Strategy. Singapore: McGraw-Hill International.

Watson, D.L., deBortali-Tregerthan, G., \& Frank, J. (1984). Social Psychology Science and Application, Glenview, 111.: Scott, Foresman and Company.

Wrightsman, L.S. (1981). Social Psychology in The 80s 3rd edition. Monterey: Brooks/Cole Publishing Co., 1981 